УДК 17.51

\title{
НАСТОЯЩАЯ ЛЮБОВЬ: КАК МЫ МОЖЕМ ЕЁ ИДЕНТИФИЦИРОВАТЬ?
}

\author{
Литовских Анастасия Сергеевна \\ Научный руководитель: Морарь Наталья Валериевна \\ учитель \\ Теоретический Лицей Имени «Андрея Страйста» \\ Новые Анены, Республика Молдова
}

\begin{abstract}
Аннотация: Понятие любви имеет несколько толкований в религии, литературе, психологии. Труднее всего дать определение понятию «настоящая любовь», которое стремится знать каждый человек. Это зависит от определенных условий: понимания, принятия, влечения, жертвы и всего, что проявляется только со временем. В исследовании мы анализируем путь, ведущий к настоящей любви между мужчиной и женщиной, используя знания из литературы, психологии, физики, религии.

Ключевые слова: любовь, настоящая любовь, ипостаси любви, условия трансформации, общечеловеческие ценности.
\end{abstract}

\section{TRUE LOVE: HOW CAN WE IDENTIFY IT?}

\author{
Litovschih Anastasia \\ Scientific adviser: Morari Natalia \\ High School „Andrei Straista” \\ Anenii Noi, Republic of Moldova
}

\begin{abstract}
The concept of love has several interpretations in religion, literature, psychology. The most difficult to define is the notion of "true love", to which every person tends to know. It depends on certain conditions: understanding, acceptance, attraction, sacrifice and all manifested only in time. În studiu analizăm calea care duce la iubirea adevărată dintre bărbat și femeie, utilizând cunoștințe din literatură, psihologie, fizică, religie.
\end{abstract}

Key words: love, true love, the hypostases of love, conditions of transformation, general-human values. 
Исходя из утверждения Вольтера: «без любви грустно быть человеком», мы понимаем, что любовь - это смысл жизни на земле, потому что тот, кто не любил, можно сказать, что не жил, любовь - это самое нежное, приятное и невинное чувство, которое может чувствовать человек, таким образом, любовь это сама жизнь.

О любви писали в религиозных текстах, в литературных произведениях, в различных книгах психологии и личного развития. Сегодня у подростка есть все эти источники информации, благодаря интернету. В то же время, о любви обсуждают в школе, дома, между друзьями. Но это, тем не менее, недостаточно объяснено понятием настоящая любовь и, соответственно, достаточно понятным, чтобы его можно было распознать и, особенно, сохранить с течением времени. Мы считаем, что если будет проанализирован путь, по которому может быть достигнута настоящая любовь, то благодаря пониманию этого явления со временем можно будет идентифицировать и сохранить чувство, которое придает смысл жизни - любовь. Это гипотеза, из которой начинается наше исследование. Объектом исследования является понятие настоящая любовь. Мы рассмотрим концепцию с научной точки зрения, обратившись к словарю, к переводу с румынского, русского и английского языков, к подходам психологов и писателей. А литературная работа, на основе которой мы рассматриваем пример истинной любви, это роман «Домашнее задание» Николая Дабижа. Цель исследования - представить концепцию настоящей любви и привести пример на основе романа Николая Дабижа.

Предложенными целями являются:

1. Объяснить концепцию настоящая любовь;

2. Проанализировать пример того, что ему предлагают главные герои романа, написанного $H$. Дабижей с точки зрения проанализированной концепции;

3. Предложить собственную модель объяснения концепции настоящая любовь;

4. Сформулировать рекомендации по признанию и сохранению истинной любви с течением времени.

Мы использовали методы текстового анализа: анализ информационных элементов текста; лингвистическая интерпретация и содержание; методы исследования: анализ понятий, сравнение, обобщение. Научная новизна работы состоит в том, чтобы предложить модель понимания концепции настоящая любовь. 
Полученные теоретические результаты: анализ концепции настоящей любви на примере Романа «Домашнее задание» Н. Дабижа. Практические результаты: рекомендации, разработанные для подростков, чтобы они могли распознать настоящую любовь и сохранить ее со временем.

На румынском языке есть три слова, которые касаются одного и того же чувства «dragoste» (любовь), «раsiune» (страсть), «iubire» (любовь), а в литературе мы не находим однозначного ответа со ссылкой на различия или сходства между этими понятиями. Таким образом, эта концепция имеет множество определений и объяснений в различных областях, но в словаре мы определили, что любовь означает «чувство привязанности к кому-то или чемуто; чувство привязанности к человеку; страсть». В литературе она объясняется как явление, например в романе «Домашнее задание» Николая Дабижа, любовь определяется как: «Истинная любовь, [...], приходит как вихрь, поднимается кругами, кружит вас, у вас кружится голова и - если вы не научитесь ходить по облакам - вы падаете сверху и остаетесь на земле. Горе тому, кто знал этот полет, он не забудет его, и с трудом научится ходить рядом с другими людьми, по дороге, по тропе...»[1, с. 168]

В религии любовь объясняется апостолом Павлом как Божественный дар: «долгая любовь терпит, любовь доброжелательна, она не завидует, не хвастается, не притупляется. Любовь не ведет себя ненадлежащим образом, не ищет своего, не злится, не думает плохо. Они не пользуются несправедливостью, но радуются истине, страдает, верит, надеется, терпят. Любовь никогда не падает» [2, с. 62]. Анализируя данные определения, мы понимаем, что любовь может быть космической, безответственной, платонической, но все же она может проникнуть в глубь души каждого из нас, тем самым изменяя нашу жизнь и судьбу. Следовательно, мы делаем вывод, что чувство любви известно во всех сферах и прославляется как самое важное чувство в жизни человека.

В разных культурах / языках чувство любви имеет одинаковое роль. На английском языке противоречит этому чувству слова love и passion, а на русском языке они любовь и страсть (например пословицы: Love is not found in the market (Любовь - это не поместье для аренды) Любви золотом не купишь) [3, с. 47]. Будучи на лингвистическом уровне выраженным по-разному на всех трех языках, идея такая же: любовь не является хорошим материалом, вы не можете купить её золотом, и вы не можете арендовать её. У россиян нет препятствий для любви: ни бедности, ни дистанции, а смысл жизни в этом - 
любовь. Молдаване и англичане утверждают, что любовь - это как лекарство [3, c. 49].

В данном исследовании мы используем слово любовь для обозначения чувства между двумя людьми, которые любят друг друга.

Некоторые исследователи выделяют для любви несколько ипостасей: любовь $\kappa$ земле как щедрому жилому пространству, $\kappa$ жизни как главному смыслу человеческого существования, $\kappa$ стране - уникальной духовной вселенной для ее людей, к человеку - ценной личности, к родителям - зародыши человеческой преемственности, по отношению к женщине / мужчине - Граалю человеческой жизни и цветку любви, по отношению к детям - прекрасный смысл человеческого существования на Земле.[4, с. 393] Самой изученной и исследованной ипостасью любви всех времен остается любовь к женщине / мужчине, потому что это тот тип любви, который оказывает наибольшее влияние на нашу судьбу и ведет к преемственности человечества.

В своей книге «Пять языков любви» автор Чепмен Г. выделяет множество языков любви: высказывания, время проведенное в двоём, подарки, услуги и физический контакт [5, с. 223]. Исследователь Виктория Кику, анализируя эту статью, приходит к выводу, что если два человека не понимают друг друга, то они используют разные языки любви [6, с. 235]. Таким образом, успех отношений зависит от способности другого человека понимать, становясь фактором, влияющим на это чувство.

В литературе есть несколько видов любви, но самые важные остаются: любовь как инициация, любовь как страсть и трагическая любовь [7, с. 66]. Любовь как страсть наиболее распространена в литературе, проявляется через взаимную любовь, преодоление препятствий и необходимость нарушить закон для выполнения миссии души. В большинстве случаев пары разделены обстоятельствами, потому что препятствия, возникающие между ними, призваны подтвердить чувства и усилить страсть между влюбленными. Любовь - страсть характеризуется страданиями, препятствиями, безумными поступками и жертвами.

Таким образом, концепция истинной любви представляет собой чувство, которое объединяет мужчину и женщину, которая преодолевает любые препятствия, возникающие во времени, основанные на взаимопонимании и принятии, придавая смысл всей жизни.

Великий современный писатель, подошедший в своем романе к теме любви-страсти, - это Николае Дабижа в романе « Домашнее задание ». В начале 
романа герои - двое красивых молодых людей. Она - старшеклассница, выпускница села Пояна. Он - молодой учитель румынского языка и литературы, увлеченный человек и пропагандист творчества великого национального поэта Михая Эминеску. Мария Рэзешу сталкивается с препятствиями, чтобы найти в другом конце мира того, кто её любит, мотивируя это возвратом заимствованной книги [7, с. 68]. И великое подтверждение любви этих двоих, в прзнании Михая «я люблю тебя», заставляет женщину, связанную, избиваемую и затащенную в тюрьму солдатами, воскликнуть: «Михай Улму, в эти моменты мне хочется кричать от счастья!» [1, с. 149]. Со всеми препятствиями, которые вмешиваются в их жизнь, они продолжают любить друг друга, они не сдаются, любовь мотивирует их бороться за жизнь и терпеть пытки, которым они подвергаются изо дня в день. Таким образом, они являются примером пары, живущей настоящей любовью, которая терпит всё, прощает всё и побеждает всё, придавая смысл существованию в целом. Любовь была той, которая подпитывала их души и давала им энергию, необходимую для выживания, а также надежду на преемственность человека через ребенка, рожденного в любви. В начале романа мы определяем момент любви двоих, проявляющийся во взаимном притяжении, и на протяжении всего романа мы наблюдаем, как герои проходят через страдания, препятствия, принятие, понимание, борьбу, чтобы наконец обнаружить, что состояние влюбленности превратилось в настоящую / исстенную любовь.

Интересно, как на этом пути формировалась настоящуая любовь, если все начиналось с состояния любви, которое было добавленно способности любить людей / соседей, то есть общечеловеческих ценностей, которые были у главных героев, и заканчивалось исполнением судьбы через любовь.

Таким образом, проанализировав историю любви, представленную в романе, мы постараемся объяснить, с нашей точки зрения, в каком контексте появляется настоящзая любовь в жизни человека, как ее можно распознать, когда она появляется, и что нужно сделать, чтобы сохранить её.

В этой статье объясним концепцию настоящей любви по сходству с принципом работы паровоза.

Всем известно что вода кипит при 100 градусов. При этой температуре можно приготовить пищу, которая, в свою очередь, сохранит вашу жизнь, придав организму энергию. Но если бы мы увеличили температуру, по крайней мере, на один градус, вода превратилась бы в пар, который мог бы привести в 
движение даже паровоз. Эта добавленная температура означала бы, на наш взгляд, по аналогии, особенно интенсивное эмоциональное состояние, которое на самом деле представляет страсть (согласно пояснительному словарю). Интенсивность эмоций, то есть страсть, будет иметь тот же эффект, что и пар, образованный при высоких температурах. То есть, человек в целом способен любить все что его окружает, любовь это общечеловеческая ценность, но если он начинает любить кого-то с большей интенсивностью, то есть со страстью, то любовь людей захватывает очертания особой любви, посвященной только одному человеку. Таким образом, когда происходит больше, чем обычная любовь к людям, тот, кто любит, получает толчок к движению / действию, поэтому получается, что эта степень порождает чувство влюбленности, специфическое между мужчиной и женщиной. Влюбленный способен изменить свою судьбу, покорить новые горизонты, так как любовь дает влюбленному неописуемую силу, будучи в состоянии двигать и горы с места.

Первоначальная влюбленность способна объединить двух людей через физическое и душевное влечение, но у нее нет силы сопротивления во времени. Из этого следует, что необходимо определенные условия, чтобы любовь выдержала время и таким образом превратилась в настоящую любовь. На наш взгляд, эти условия: взаимопонимание, жертва, принятие, и всё проявляются с течением времени. Соблюдение этих условий подтверждает существование истинной любви, которая представляет энергию, которая движет людьми к великим деяниям. Хорошим примером является борьба за выживание героев романа, о которой говорилось ранее. Только благодаря любви персонажи выдержали препятствия, сохранили чувство и родили ребенка, тем самым придав особый смысл всему человеческому существованию.

Любовь это то, что даётся, божественный дар, это главный элемент, из которого состоит человеческое вещество, потому что от любви к человеку божество и создал человека. Это называлось «любовь», в основном направленное на вибрации, изменения и реакции физиологической и человеческой психики. Вот почему и концептуализация любви как феномена, и разнообразие ипостасей ее переживания явно прослеживаются в произведениях искусства, любовь становится одной из великих тем всемирной литературы наряду с темами времени, природы, космоса, человеческой судьбы и др. [4, с. 392]

Следуя анализу концепции с разных точек зрения, а также анализу примера в романе, мы формулируем некоторые рекомендации для подростков, 
которые хотят знать, что такое настоящзая любовь, и хотят быть готовыми признать ее в будущем:

$>$ Любить по-настоящему означает быть способным к жертвам, пониманию, принятию друг друга со всеми потребностями и устремлениями;

$>$ Любовь начинается с понятия влюбленности, но она становится настоящей только со временем, когда пара проявляет уважение, понимание, принятие и способна жертвовать ради блага другого;

$>$ Человек не может осознать настоящую любовь сразу же, по тому что это требует времени, чтобы утвердить себя;

$>$ Истинная любовь это ипостась любви в общем смысле. Другими словами, настоящую любовь можно заслужить только в том случае, если вы уже усвоили общечеловеческие ценности, такие как: любовь к ближнему, уважение и осознание всего, что вас окружает.

В заключение можно сказать что на истинную любовь способен только человек с ценностями, который понимал и другие ипостаси любви (природы, Родины, людей в целом). И человек, который действительно любит, понимает смысл человеческого существования. Если он не готовится через чтение, через знание, через эмпатию, проявляемую к литературным персонажам, через любовь ко всему что его окружает, то молодой человек может не признать любовь или рискнуть потерять ее, со временем.

\section{Список литературы}

1. Дабижа Н. Домашнее задание, Кишинев: Издательство Литературы и Искусства, - 2018, - 365 с.

2. Требник. Издательство монастыря «Святого Вознесения», - 2008, Слобозия, с. Кицкань

3. Лифари В. Лингво-культурная концепция любви в английских, румынских и русских пословицах. // Интеграция через исследования и инновации. Гуманитарные науки, Кишинев, - 2014, - С. 47-50.

4. Кристей Т. Концепция любви в видении Адриана Пэунеску. // Перспективы и проблемы интеграции в европейское пространство исследований и образования. Том 7, Часть 2, Кагул, - 2020, - С. 392-397.

5. Чапман Г. Пять языков любви. Бухарест: Curtea veche, - 2015, - 223 с.

6. Кику В. Стили привязанности и языки любви у молодых людей'. // Национальная сессия с международным участием студенческих научных 
коммуникаций, естественных и точных наук. Том Кишинев: Редакционнополиграфический центр МГУ, - 2020, - С 234-236

7. Корчинский Н. Восстановление христианской любви в современной литературе. // Современная Филология: достижения и перспективы в европейском контексте наследие, влияние, преемственность. Выпуск 12, Кишинев, - 2019, - С. 65-69.

(C) А.С. Литовских, 2021 